\title{
sciendo
}

\section{DIETARY STRATEGIES TO ENRICH MILK WITH HEALTHY FATTY ACIDS - A REVIEW}

\author{
Ahmed E. Kholif ${ }^{1 *}$, Olurotimi A. Olafadehan ${ }^{2}$ \\ ${ }^{1}$ Dairy Science Department, National Research Centre, 33 Bohouth St. Dokki, Giza, Egypt \\ ${ }^{2}$ Department of Animal Science, University of Abuja, Abuja, Nigeria \\ •Corresponding author: ae_kholif@live.com; ae.kholif@nrc.sci.eg
}

\section{Abstract}

Feed is the main factor impacting the composition and quality of milk of dairy animals. Therefore, the present review explores the effects of feed and nutrition on milk fat content and levels of healthy fatty acids (FA) in milk consumed by humans. Milk and dairy products are two main sources of healthy and unhealthy FA in human nutrition. The concentrations of FA in milk depend mainly on diets; therefore, milk FA concentrations and ratios can be greatly altered by some feeding strategies. Dietary supplementation of the diets of dairy livestock with vegetable seeds or oils, microalgae and phytogenic feed additives, and feeding of some grasses can enhance the contents of healthy FA, including n-3 FA, $\alpha$-linolenic acid, conjugated linoleic acid (CLA) and, generally, unsaturated FA in milk and dairy products. Enrichment of milk with healthy FA may make milk a source of anticarcinogens (CLA and polyphenols) for human health. This review, therefore, focusses on the current research findings on enrichment of milk with healthy FA and summarizes some effective supplementation strategies to alter milk FA profile.

Key words: fatty acids, feed additives, feed supplement, health, milk

Improving the yield and composition of foods (e.g., milk and milk products) are not the only main objectives of agricultural research but also improving the quality (i.e., nutritive value). Recently, new concerns regarding the production of functional foods have compelled animal nutritionists and microbiologists to explore any practices that can improve the profile of fatty acids (FA), particularly health beneficial FA, of food products (Gebreyowhans et al., 2019). Foods of animal origin (e.g., milk, milk product, and meat) are vital sources of essential nutrients (minerals, quality proteins, and vitamins) and energy to humans. Additionally, milk and milk products contain considerable amounts of FA, both saturated FA (SFA) and unsaturated FA (UFA). Milk quality depends mainly on its technological and coagulation properties, which are mainly affected by the milk protein and fat concentrations (Nudda et al., 2014). The compositions of fats and FA depend primarily on feed (composition and availability) and other secondary factors, such as genetics, physiological status, and age of animals. The profile of FA in milk can greatly be altered by nutritional factors, particularly dietary fat supplementation (Morsy et al., 2015; Thanh and Suksombat, 2015; Kholif et al., 2016 a, 2018 c; Gebreyowhans et al., 2019; Kliem et al., 2019).

High intake of SFA in human diet increases the risk of cardiometabolic and cardiovascular diseases and lowers insulin sensitivity, resulting in increased metabolic disorders and diabetes. Increasing the consumption of UFA, especially those of n-3 FA such as eicosapentaenoic acid (EPA), $\alpha$-linolenic acid (ALA), and docosahexaenoic acid (DHA), is healthful as it reduces susceptibility to cardiovascular diseases and inflammation, and improves immune function, mental health and development, and central nervous system (Erdman et al., 2011; Gutiérrez et al., 2019). Altering the concentrations of FA to increase the quantities of essential FA (ALA, EPA, DHA, or other n-3 FA) and reduce the concentrations of SFA in milk and its products is essential to the health of consumers (Gebreyowhans et al., 2019).

Enrichment of ruminant milk and milk products with healthy FA is of invaluable importance due to the reported benefits from the studies on their roles in human health (Sofi et al., 2010; Gebreyowhans et al., 2019). Sofi et al. (2010) observed that weekly intake of $200 \mathrm{~g}$ of sheep cheese naturally fortified with vaccenic acid and conjugated linoleic acid (CLA) (3.26 and $1.56 \%$ of lipids, respectively) for 10 weeks resulted in pronounced positive biochemical changes of atherosclerotic markers. Additionally, Pintus et al. (2013) noted that intake of sheep cheese naturally enriched with CLA at $2.5 \%$ of fat remarkably decreased the plasma concentrations of the endocannabinoid anandamide and low-density lipoprotein-cholesterol level by $7 \%$ compared with a control cheese containing $1.5 \%$ of fat. The review discussed various approved approaches that alter and enrich milk and dairy products with beneficial and healthy FA. Effects of feeding and enriching diets of animals with vegetable 
seeds and oils, FA rich microalgae, phytogenic feed additives, and other feed supplements on milk FA profile are discussed in detail. For the purpose of this review, feed additive refers to non-nutritive substance added to feed in micro quantities to enhance feed utilization efficiency and improve animal performance, while feed supplement is used to describe additional nutritive materials, containing phytogenic substances/secondary metabolites, given to animals to enhance feed utilization.

\section{Milk fat, fatty acids, and biohydrogenation}

Fat in milk occurs in the form of globules of varying sizes, with the triglycerides enclosed in a triple-layer membrane. The fat globules (i.e., diameter) number and size depend on such factors as physiology, environment and genetics. Triacylglycerols, accounting for more than $98 \%$ of lipids in livestock milk, comprise glycerol and three FA with diverse carbon chain lengths (Nudda et al., 2014). Milk FA are synthesised and secreted by the mammary gland epithelial cells, using plasma uptake or de novo synthesis as the main source. Ruminal acetate and beta-hydroxybuyrate obtained during fermentation are the sources of the de novo synthesised milk FA. The de novo synthesis of FA produces all the short-chain FA (C4:0-C14:0) and part of C16:0, while the remaining part of $\mathrm{C} 16: 0$ and virtually all of the milk long-chain FA (C18:0-C22:0) emanate from circulating blood lipids and absorption in the small intestine or mobilization of adipose tissue (Nudda et al., 2014). However, the activity of desaturase enzymes may further modify the C14:0 C18:0 FA in the mammary gland. Additionally, odd and branched-chain FA in milk fat are obtained largely from the intestinal absorption of lipids from the bacteria membrane coming from the rumen (Vlaeminck et al., 2006).

Milk fat content and composition depend mainly on the diet of animals and can be dramatically changed by altering ruminal fermentation, especially acetate and acetate/propionate ratio (El-Zaiat et al., 2019; Azzaz et al., 2020). The proportions of ruminal acetate, butyrate, and propionate depend on dietary neutral detergent fibre (NDF) and non-fibre carbohydrates (NFC). Cannas (2009) recommended NDF ranging from $33 \%$ to $45 \%$ and NFC ranging from 28 to $38 \%$ of the diet as levels for optimal ruminal function, milk production, and fat concentration. Moreover, milk fat content and composition greatly depend on the energy balance of animal, especially in early lactation. Negative energy balance increases milk fat level and its content of long-chain preformed FA as a result of the absorption of non-esterified FA obtained from mobilization of body fat in the mammary gland (Pulina et al., 2006).

Feeds and pattern of ruminal fermentation are responsible for milk FA variation. Production of trans FA isomers in the rumen causes depression of milk fat, and ruminal biohydrogenation of FA provides a clue to the source of specific trans FA isomers used by the mammary enzymes for secretion in milk (Tripathi, 2015). The ability of ruminal microbial biohydrogenation, which transforms the UFA of dietary fat to saturated FA, to change milk FA composition irrespective of the dietary FA composition is limited. This, therefore, limits the transfer of UFA to mammary tissue even at high dietary concentration. Ruminal microflora are responsible for biohydrogenation, a process involving addition of hydrogen through microbial enzymes and elimination of double bonds in a fatty acyl chain and their conversion from UFA to SFA. The roles played by ruminal microorganisms in regulating pathway of FA biohydrogenation for successful nutritional manipulation of milk constituents are imperative. Trans FA and milk fat depression are the consequences of the intermediates of trans FA, which arise from the biohydrogenation pathways. Conjugated linoleic acid, an essential biohydrogenation intermediates in milk fat, is beneficial to human health due to its anticarcinogenic properties. Similarly, the cis-9, trans-11 CLA isomer, which arises from linoleic acid biohydrogenation, possesses special anticarcinogenic properties. The process of improving milk biohydrogenation intermediates, which involve knowing the origin and probable enhancement of ruminal beneficial FA isomers, was identified by a multitude of positional and geometric trans isomers produced from ruminal lipid biohydrogenation. Greater than 10 positional isomers of trans monoene FA and a dozen or more CLA isomers have been isolated in the contents of ruminants intestine. Biohydrogenation of linolenic and linoleic acids produced a trans-10 double bond intermediate. Ruminal bacteria can produce a trans-10, cis-12 CLA, while mixed rumen microorganisms can convert oleic acid to trans FA and also produce a trans-10 isomer (Tripathi, 2015).

Table 1. Effect of pasture-based diets on milk fatty acid profile

\begin{tabular}{|c|c|c|c|c|}
\hline Treatment & Animal & Diet & Effects $^{*}$ & Reference \\
\hline $\begin{array}{l}\text { Annual ryegrass, sulla, burr medic } \\
\text { and a daisy forb }\end{array}$ & Sarda ewes & Four plants & $\begin{array}{l}\text { Legume-based pastures: } \\
\uparrow \text { CLA and ALA } \\
\downarrow \text { SFA }\end{array}$ & $\begin{array}{l}\text { Addis et al. } \\
(2005)\end{array}$ \\
\hline Grass silage and maize silage & Holstein-Friesian cows & $\begin{array}{l}\text { Total mixed ration containing } \\
\text { grass silage or maize silage }\end{array}$ & $\begin{array}{l}\text { Maize silage: } \\
\downarrow n-3 \text { FA, ALA and EPA } \\
\uparrow n-6 / n-3 \text { ratio }\end{array}$ & $\begin{array}{l}\text { Kliem et al. } \\
(2008)\end{array}$ \\
\hline Grazing perennial rye grass or grass silage & Holstein cows & $\begin{array}{l}\text { Perennial rye grass sward and } \\
\text { grass silage }\end{array}$ & $\begin{array}{l}\text { Fresh grasses: } \\
\uparrow \text { ALA }\end{array}$ & $\begin{array}{l}\text { Mohammed et } \\
\text { al. (2009) }\end{array}$ \\
\hline
\end{tabular}

$\uparrow=$ increased, $\downarrow=$ decreased, $1=$ no effect

*Effect is relative to control.

$\mathrm{ALA}=\alpha$-linolenic acid; CLA $=$ Conjugated linoleic acid; EPA $=$ Eicosapentaenoic acid; SFA $=$ Saturated fatty acids 


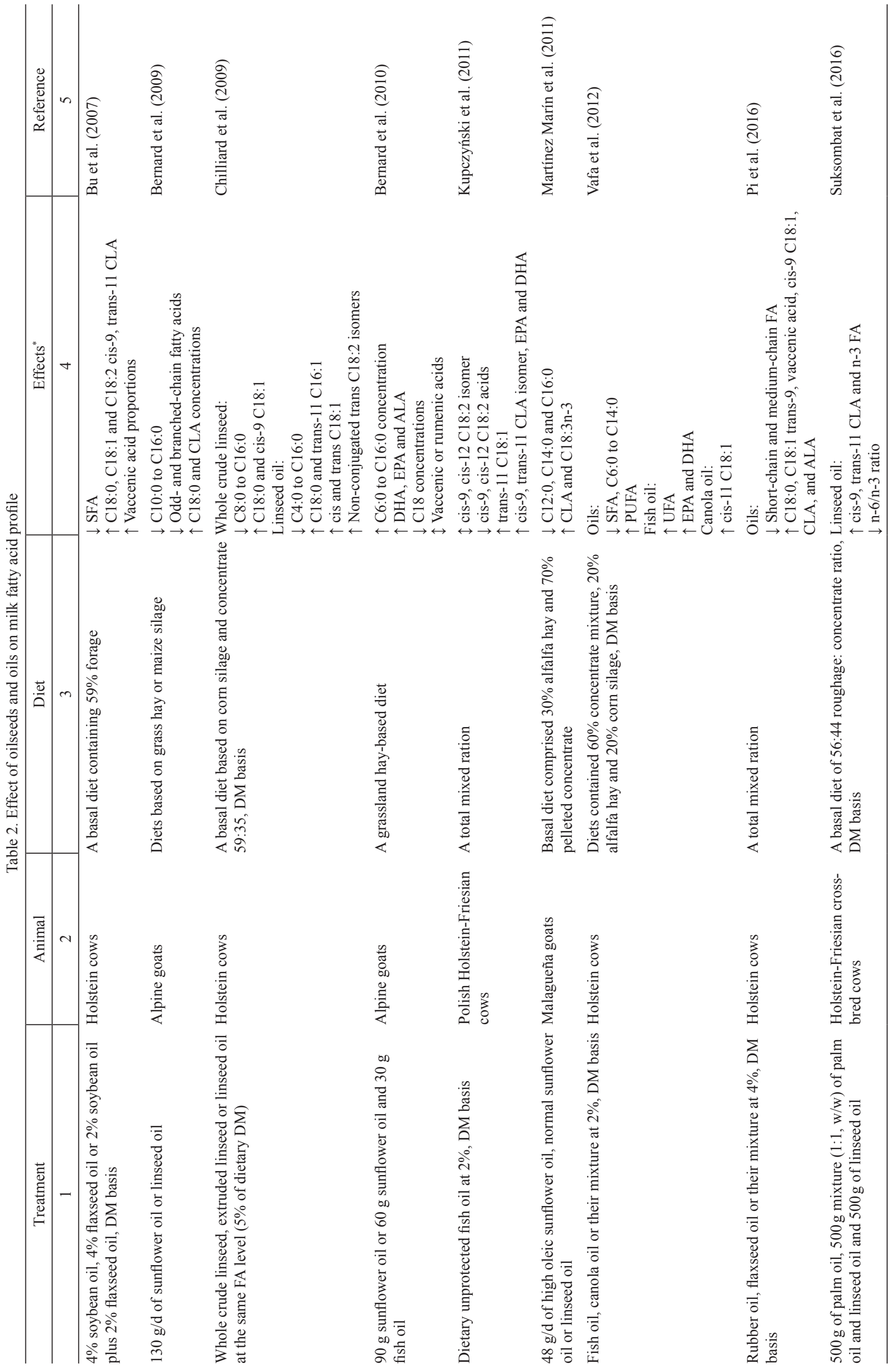




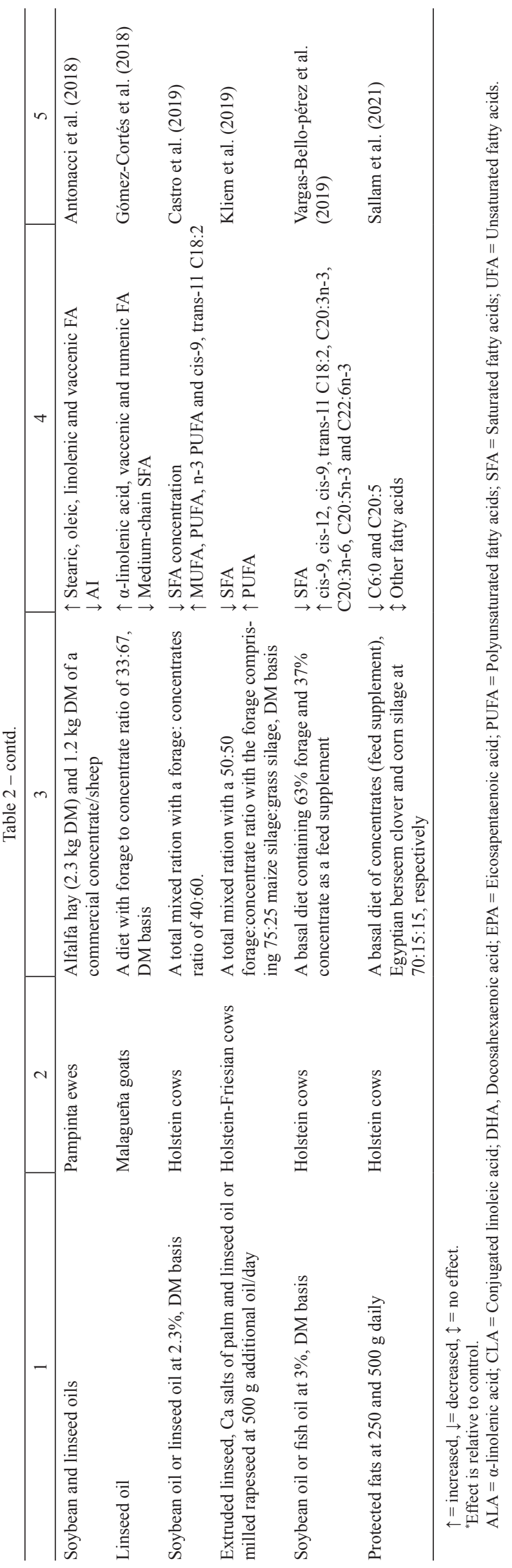




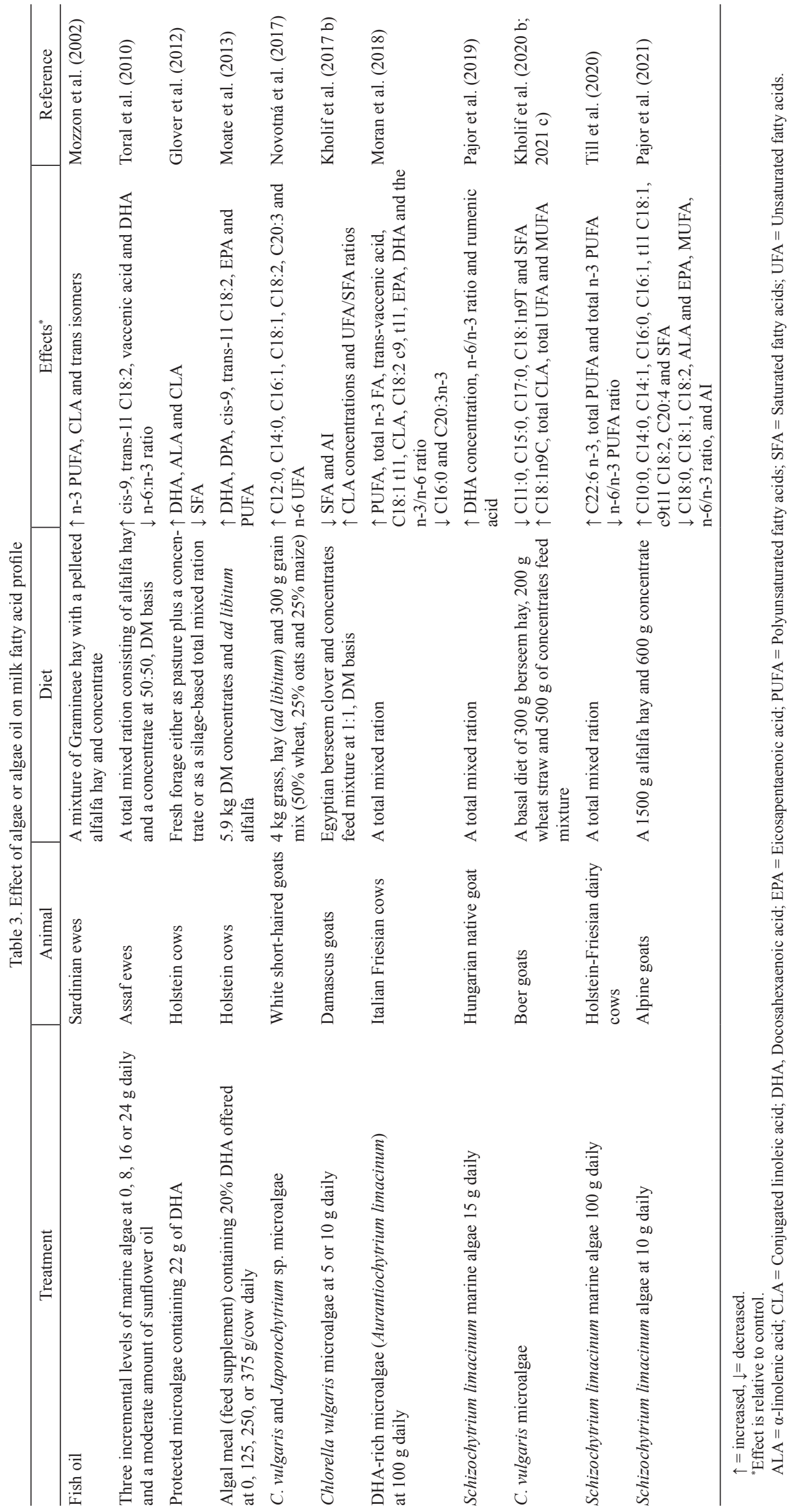




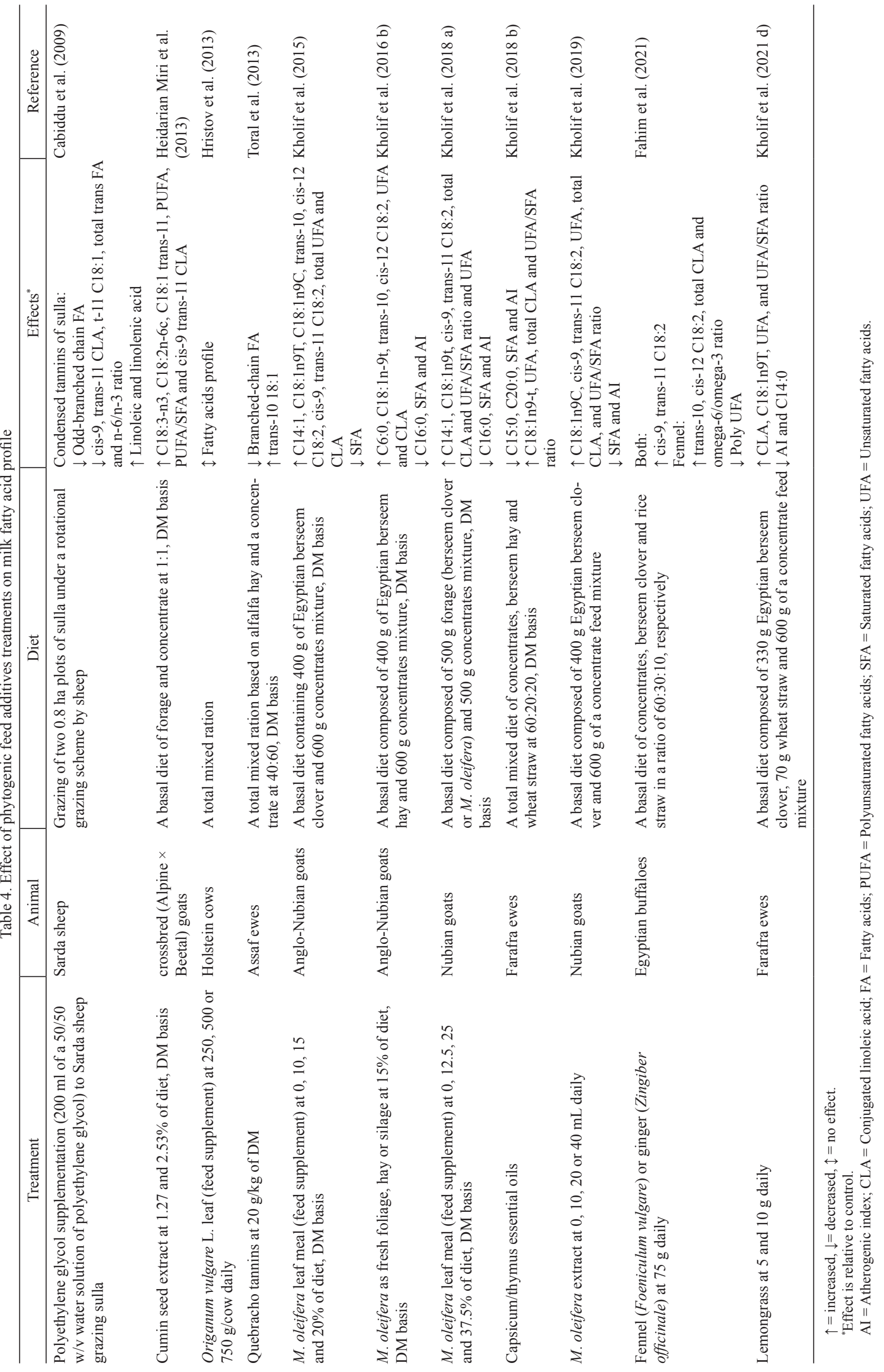




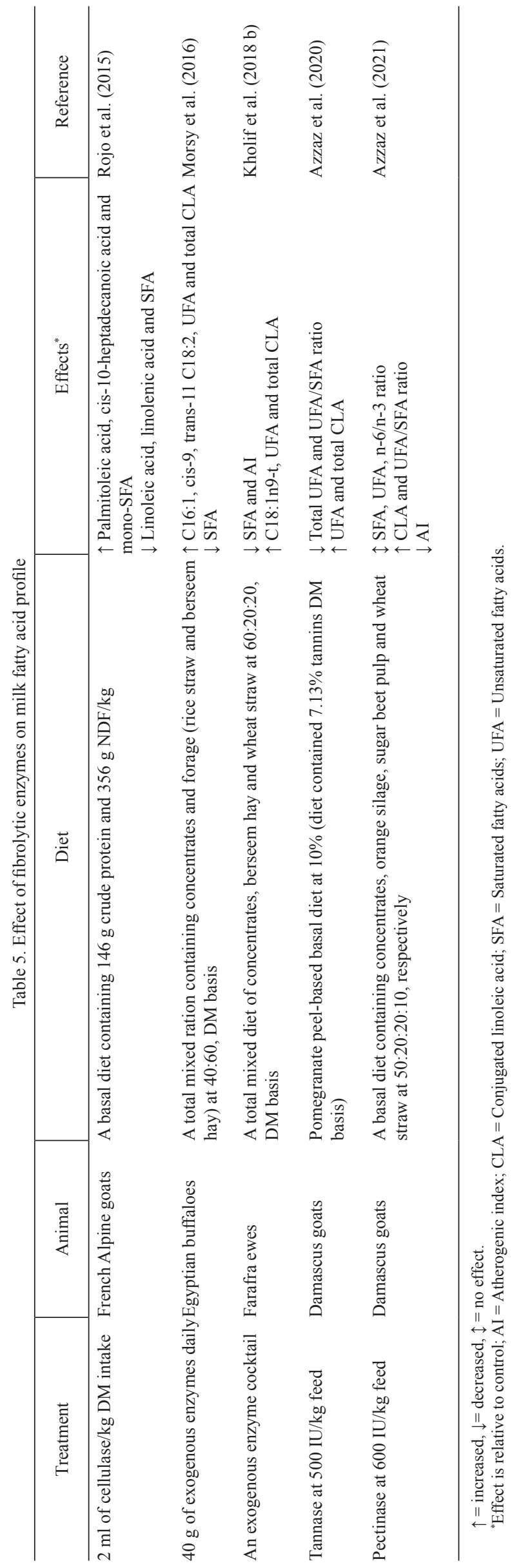




\section{Enrichment of milk with healthy FA}

Many feeding strategies such as the amount and types of feed supplement, especially secondary metabolites containing forage, and addition of vegetable or marine oils and algae to diets have been shown to cause major variation in milk FA composition because of the effect of these factors on the process of ruminal biohydrogenation of dietary UFA (Nudda et al., 2014; Gebreyowhans et al., 2019).

\section{Effects of pasture-based diets}

Table 1 summarizes the effect of pasture-based diets on milk FA profile. In their review, Kalač and Samková (2010) showed that grasses are the main and cheapest source of FA in ruminant diet, though they contain relatively low ( 2 to $5 \% \mathrm{DM}$ ) total FA concentration. Some feed supplements, like green pasture, are an excellent source of ALA fatty acid, presenting about $50-75 \%$ of the total FA (Chilliard et al., 2007). The ALA is considered as one of the most effective FA affecting milk FA composition and contributing to increased healthy FA (Dewhurst and Moloney, 2013; Nudda et al., 2014; de la TorreSantos et al., 2020). The green pasture ALA is partially biohydrogenated in the rumen to vaccenic acid, released into milk, and partly transformed to cis-9, trans-11 CLA by the action of stearoyl-CoA desaturase in the mammary tissue (Nudda et al., 2014). De Renobales et al. (2012) observed strong relationships between green pasture intake and ALA milk content $\left(R^{2}=0.69\right)$ and CLA $\left(R^{2}=\right.$ 0.79). de La Torre-Santos et al. (2020) compared the effect of mode of grass provision (grazing, zero-grazing, or ensiling) on the performance of dairy cows and observed that cows on grazing treatment had greater proportions of vaccenic and rumenic acids, and C18:1 trans-11/C18:1 trans-10 ratio compared with cows on zero-grazing and grass silage treatments. Additionally, they observed increased proportion of linoleic acid for the grazing treatment, while treatments had no effect on ALA, SFA, UFA, or $\mathrm{n}-6 / \mathrm{n}-3$ ratios.

The species of pasture affects milk FA profile (Nudda et al., 2014). Addis et al. (2005) observed that the milk of sheep fed legume-based pastures, as a feed supplement, showed greater CLA and ALA contents and lower content of SFA relative to the milk of sheep fed ryegrass pasture. They also observed that the intake of crown daisy (Chrysanthemum coronarium L.) and sulla (Hedysarum coronarium L.) favoured greater level of CLA in milk fat. Kliem et al. (2008) noted that maize silage replacement for grass silage decreased milk total n-3 FA, ALA, and EPA and improved $n-6 / n-3$ ratio. In addition to increasing milk ALA content, increased EPA and DHA contents were obtained from cows kept under grass-based diet (Kalač and Samková, 2010).

The physical form of pasture can also affect milk FA profile. Mohammed et al. (2009) observed improved milk ALA content with fresh grasses compared with conserved grasses. Cabiddu et al. (2006) attributed pronounced effect of forage species on cheese FA composi- tion to varied feed FA composition and intake. In many experiments, grass-based diet increased ALA content from 0.10 to $0.33 \%$ of FA and decreased SFA content from 6.66 to $2.00 \%$ of FA in the milk of ruminants compared with total mixed ration-based feeding (Kalač and Samková, 2010; Rego et al., 2016).

\section{Effect of plant seeds and oils}

Table 2 summarizes the effect of different oils and oilseeds on milk FA profile. Vegetable oils and oilseeds are a veritable tool to improve diet energy content and alter milk FA composition (Kholif et al., 2016 a, 2018 c; Castro et al., 2019), especially in animals fed diet having a poor content and composition of FA. The proportion of individual FA in milk is dependent on the dietary fat content, type of dominant fat, and physical form of fat supplement. Nudda et al. (2014) analyzed data of many experiments and reported a positive correlation $\left(R^{2}=\right.$ 0.78 ) between the quantity of linoleic and linolenic acids rich supplementary fat and the milk CLA content. Vegetable oils and oilseeds affect the concentration of milk FA, either directly by direct absorption of FA into milk or indirectly by modifying lipogenic enzymes expression (Gebreyowhans et al., 2019).

Many oilseeds and oils have been adjudged to affect milk contents of FA. Flaxseed and flaxseed oil (Kholif et al., 2018 c; Castro et al., 2019), soybean oil (Castro et al., 2019), and sunflower seeds and oil (Morsy et al., 2015) are among the sources of supplementary healthy FA (e.g., n-3 and CLA) commonly used in ruminants. Soybeans, linseed (flaxseed), sunflower, and safflower are the predominantly used unsaturated plant lipids sources to improve CLA and UFA concentration in milk fat (Castro et al., 2019). Soybean oil is more effective than linseed oil or sunflower oil in increasing the milk CLA content (Nudda et al., 2014; Castro et al., 2019), indicating a more complete ruminal biohydrogenation of UFA in animals offered linseed oil or sunflower oil relative to those supplemented with soybean oil. Consequently, the quantity of vaccenic acid and CLA duodenal flow was higher in animals whose diets were supplemented with linoleic acid rich oil, as already postulated for dairy cows (Bu et al., 2007).

The form of oil supplementation has effect on milk FA proportions (Morsy et al., 2015; Kholif et al., 2018 c). Bodas et al. (2010) observed that vegetable fat supplements in the form of free oil (extracted oil) are usually more effective than those in the form of whole seeds at enhancing the CLA content of milk. However, Kholif et al. (2018 c) reported that crushed flaxseed is preferable to flaxseed oil in enhancing milk FA proportions, while Morsy et al. (2015) did not observe any differences between the effect of sunflower oil or seeds on milk FA proportions. Oil inside intact seeds is released gradually whereas oil extracted from the seed is immediately available in the rumen.

Processed dietary fats (e.g., extruded, rolled, micronized, or roasted seeds) generally effectively increase 
CLA content of milk compared to raw seeds (Kliem et al., 2019). This is possibly because of slow and complete release of the oil content of raw seeds in the rumen relative to the processed seeds, which have a reduced effect on the ruminal environment. Kliem et al. (2019) showed that extruded linseed oil supplementation to lactating cows increased ALA and total n-3 FA contents and decreased total SFA content and n-6/n-3 ratio. Others (Suksombat et al., 2016) observed improvements in milk ALA and total n-3 FA contents and reductions in milk total SFA concentration and n-6/n-3 ratio with un-extruded linseed oil or whole linseed supplementation to lactating cows.

Increased concentration of healthy FA (e.g., ALA and total n-3 FA) with feeding of extruded oil is perhaps due to improved digestibility, as extrusion assists in enhancing digestibility. The safe level of n-3 FA supplementation in the diet, which prevents impairment of rumen function, is around $2-3 \%$ of DM (Gebreyowhans et al., 2019). Because of the extensive rumen biohydrogenation of polyunsaturated FA (PUFA), only about $2.2-3.5 \%$ of $\mathrm{n}-3$ FA consumed is released into milk, thus limiting the n-3 FA level in milk fat (Hurtaud et al., 2010). Chilliard et al. (2009) observed that supplementation of lactating cows diet with unprotected linseed oil at 5\% of DM affected milk ALA and decreased milk yield due to extensive ruminal biohydrogenation and impaired rumen function. Such results suggest that protecting FA from ruminal biohydrogenation efficiently maximize the assimilation of dietary FA into milk fat without impacting milk production.

$\mathrm{Bu}$ et al. (2007) fed lactating cows on diets supplemented with soybean seed oil at $4 \%$ and observed increased ALA and PUFA. They attributed their findings to the marginal content of ALA in soybean seed oil. Kupczyński et al. (2011) observed that supplementation of lactating cows with fish oil at 2\% DM of diet increased DHA (by $430 \%$ ), EPA (by 2000\%), and ALA (by 114\%) concentrations in milk. Vafa et al. (2012) supplemented the diet of early lactating Holstein cows with either $2 \%$ fish oil alone or $1 \%$ fish oil combined with $1 \%$ canola oil and reported increased concentrations of DHA and EPA. Pi et al. (2016) observed that feeding 4\% unprotected rubber seed oil, $4 \%$ flaxseed oil, and a combination of $2 \%$ rubber seed oil $+2 \%$ flaxseed oil to lactating cows enhanced the concentrations of ALA in milk (by $40 \%$, $86 \%$, and $51 \%$, respectively), increased the sum of n-3 FA, and decreased SFA concentrations. Recently, Castro et al. (2019) observed that feeding soybean or linseed oil decreased SFA concentration and increased UFA, n-3 PUFA, and cis-9, trans-11 C18:2. Additionally, VargasBello-Pérez et al. (2019) compared the effect of soybean and fish oils supplementation on milk FA profile of lactating cows and observed reduced concentration of SFA and increased concentrations of cis-9, cis-12 C18:2, cis9, trans-11 C18:2, C20:3n-3, C20:3n-6, C20:5n-3, and C22:6n-3. However, while sole fish oil supplementation depressed ALA concentration, it had positive impact on the ALA concentration when combined with canola oil.
Combining fish oil with linseed oil $(1: 1, w / w)$, fish oil with sunflower oil $(1: 1, w / w)$, or fish oil with linseed and sunflower oils $(1: 1: 1, \mathrm{w} / \mathrm{w} / \mathrm{w})$, Thanh and Suksombat (2015) observed enhanced n-3 FA and ALA in cow milk.

Using lactating ewes, Antonacci et al. (2018) observed that substituting soybean seed oil with linseed oil in their diet increased ALA (1.97 vs. 5.18\% FA) and n-3 FA (2.07 vs. $5.33 \%$ FA) and decreased SFA (66.50 vs. $52.29 \%$ FA) and n-6/n-3 (5.66 vs. $1.89 \%$ FA). Sunflower oil supplementation of dairy goats diet depressed SFA concentrations and improved total n-3 FA, without affecting individual n-3 FA contents (Bernard et al., 2009; Martínez Marín et al., 2011). However, others (Gómez-Cortés et al., 2018) observed increased concentrations of n-3 FA and depressed SFA and n-6/n-3 ratio in goat milk supplemented with linseed oil. Bernard et al. (2010) observed that supplementing diets of dairy goats with a mixture of fish oil and sunflower oil in ratio 1:2 w/w increased milk DHA, EPA, and ALA concentrations by $200 \%, 117 \%$, and $16 \%$, respectively relative to the concentrations in milk from sole sunflower oil supplementation. In another experiment, Toral et al. (2014) observed increased milk EPA content (from 0.03 to $0.10 \%$ ), DPA (from 0.09 to $0.15 \%$ ), and DHA (from 0.02 to $0.08 \%$ ), with increasing supplementation rate of fish oil $(0,20$, and $40 \mathrm{~g}$ daily) to goats. Bernard et al. (2016) observed that feeding goats with fish oil (40 $\mathrm{g}$ daily) containing diet resulted in milk that was rich in long-chain FA (C20:4n-3, C20:5n-3, C22:3n-3, C22:5n-3, and C22:6n-3), whereas feeding fish oil (40 $\mathrm{g}$ daily) and extruded linseed oil (360 $\mathrm{g}$ daily) generated milk that was rich in ALA, indicating fish oil as a rich source of long-chain FA ( $\geq 20$ carbon) and linseed oil as a rich source of ALA.

\section{Effect of microalgae and marine oil}

Table 3 summarizes the effect of feeding microalgae and marine oil on milk FA profile. Generally, ruminant feeds contain low amounts of DHA and EPA, which are, therefore, marginally present or totally absent in dairy products. In contrast, microalgae are rich in DHA and EPA (Gomaa et al., 2018) and are thus used as a good source of these FA in the diets of dairy animals to produce dairy products with enhanced concentrations of DHA and EPA (Lum et al., 2013; Altomonte et al., 2018).

Inclusion of full-fat, defatted, or microalgal oil to alter the profile of FA in milk has been investigated (Toral et al., 2010; Glover et al., 2012; Kholif et al., 2017 b; Till et al., 2020). Increased concentrations of milk DHA (from 1000 to $1122 \%$ ) and EPA (from 24 to $240 \%$ ) have been observed in cows supplemented with full-fat microalgae biomass (Moran et al., 2018). The transformation of DHA and EPA from feed to milk is more efficient with full-fat microalgae compared with the defatted microalgae (Gebreyowhans et al., 2019). However, Lum et al. (2013), in their review, stated that feeding of defatted microalgae biomass to dairy cows increased the DHA and EPA and decreased the SFA concentrations in milk. Till et al. (2020) noted that supplementation of dairy cow diet 
with Schizochytrium limacinum microalgae increased milk fat content of C22:6n-3, total PUFA, and total n-3 PUFA but reduced n-6/n-3 PUFA ratio.

Protecting microalgae from ruminal degradation resulted in increased levels of milk DHA ( 0.24 vs. $0.08 \%$ of FA), PUFA, particularly ALA, and CLA contents and decreased SFA content (Glover et al., 2012). Additionally, Stamey et al. (2012) observed that feeding cows on total mixed ration supplemented with algal oil increased milk DHA (by 200\%) and EPA (by 300\%). Moate et al. (2013) showed that microalgae supplementation level affected milk contents of the DHA, DPA, and EPA. They observed that increasing microalgae supplementation level up to $75 \mathrm{~g} / \mathrm{cow}$ daily increased DHA by 23 -fold, DPA by 7-fold, and EPA and cis- 9, trans-11 C18:2 by 2-fold in milk.

In sheep, microalgae supplementation increased milk contents of DHA by 9- to 19-fold, DPA by 2- to 7-fold, and EPA by 2- to 12-fold (Toral et al., 2010; Bichi et al., 2013). However, Toral et al. (2010) observed a decreased ALA content in milk produced from ewes fed microalgae.

Generally, information on supplementing diets of goats with microalgae is scarce (Kholif et al., 2020 a). Microalgae supplementation increased the concentrations of DHA, EPA, and eicosatrienoic (i.e., n-3 FA) acid in goat milk (Novotná et al., 2017). Kholif et al. (2017 b) noted increased milk UFA and CLA contents by $16.2 \%$ and $53.8 \%$, respectively, and decreased SFA concentration by $6.6 \%$ in the milk of goats supplemented with Chlorella vulgaris microalgae at 5 or $10 \mathrm{~g}$ daily. Recently, Kholif et al. (2020 b; $2021 \mathrm{c}$ ) observed that supplementing lactating Boer goats diet with $C$. vulgaris microalgae and copper decreased milk concentration of SFA and increased the concentrations of UFA and CLA. Pajor et al. (2019) observed that feeding Schizochytrium limacinum marine algae to lactating goats considerably increased the milk DHA concentration and n-6/n-3 ratio. However, Novotná et al. (2017) reported a decreased ALA concentration ( 1.18 vs. $1.04 \%$ of total FA) in the milk of control goats vs. the milk of microalgae supplemented goats.

Though marine oil is poor in CLA precursors, its supplementation increased milk vaccenic acid and CLA through the inhibition of the reduction of vaccenic acid to C18:0 by rumen bacteria. Mozzon et al. (2002) supplemented diets of ewes with protected fish oil at 30 and $45 \mathrm{~g} / \mathrm{d}$ and observed increased milk CLA content. Studies (Mozzon et al., 2002) on the effect of supplementing the diet of ewes with rumen-protected marine oil rich in EPA and DHA reported increased concentrations of these long-chain FA in milk of the supplemented ewes relative to the milk of the control ewes.

\section{Effect of phytogenics}

Table 4 summarizes the effect of phytogenics on milk FA profile. Phytogenics include many plants used as feed supplement or plant-derivative feed additives (Kholif et al., 2021 b; Shaaban et al., 2021). Tannin-rich feed sup- plements or extracts and phytogenics mixture are the most evaluated additives for altering ruminal fermentation (e.g., to decrease ammonia and methane production) and treatment of internal parasites (Khattab et al., 2017; Sallam et al., 2019; El-Zaiat et al., 2020). Due to their ability to modify rumen fermentation, they may similarly alter the FA composition of milk and cheese (Kholif et al., 2021 a). Phytogenics contain secondary compounds which exert antimicrobial effect on the rumen biohydrogenating bacterial species, causing aggregation of biohydrogenation intermediates and improvement of UFA and CLA contents of milk (Kholif et al., 2015; Kholif and Olafadehan, 2021). Phenolic compounds, such as rosmarinic, caffeic acids, tannins, flavonoids, and phenols, in plants used as feed supplements possess antibacterial activity against specific rumen biohydrogenating bacteria, producing improved absorption and accumulation of milk UFA (Kholif et al., 2017 a). Corollary to this, Cabiddu et al. (2009) observed that grazing tanniniferous Hedysarum coronarium forage, a feed supplement, increased milk ALA content and reduced vaccenic acid and CLA concentrations in milk and cheese of ewes. Additionally, Kholif et al. (2015, 2018 a) fed Moringa oleifera foliage, as a feed supplement, to lactating goats and observed a positively modified milk FA profile in the form of increased UFA (up to 29\%) and CLA (up to 58\%) and decreased SFA (up to 13\%). In another experiment, Kholif et al. (2016 b) observed that feeding fresh biomass, hay, and silage of $M$. oleifera enhanced total UFA (about 22\%) and total CLA (about 57\%) and decreased total SFA (about 9\%) and atherogenic index (AI) (about 13-27\%). Using the aqueous extract of $M$. oelifera, Kholif et al. (2019) noted that lactating goats orally supplemented with the extract at 10,20 , and $40 \mathrm{~mL}$ daily had increased milk proportions of UFA by about $11.5-13.9 \%$ and CLA by about $17.4-23.2 \%$ and decreased SFA proportion by about $4.6-5.6 \%$ compared to the non-supplemented control goats. Morsy et al. (2018) observed that supplementing diets of lactating goats with cumin (Cuminum cyminum L) seeds decreased total SFA by about $3.9 \%$ and improved UFA and total CLA by about $9.7 \%$ and $23.1 \%$, respectively. They also stated that mustard seeds increased total CLA by about $15.4 \%$. Moreover, Kholif et al. (2018 b) observed that providing oral doses of capsicum/thymus essential oils blend to lactating goats increased the concentrations of UFA and CLA and decreased SFA concentration and AI.

Toral et al. (2013) observed unaffected milk FA composition in milk of sheep fed quebracho tannin extract at $20 \mathrm{~g} / \mathrm{d}$ per ewe. Heidarian Miri et al. (2013) fed lactating goats with 12.7 and $25.3 \mathrm{~g} / \mathrm{kg}$ DM of cumin seed extract and observed increased milk PUFA and CLA. Kholif et al. (2017 a) showed that feeding lemongrass and rosemary (Rosmarinus officinalis spp.) to lactating goats at $10 \mathrm{~g}$ daily increased UFA and UFA/SFA ratio by approximately $9 \%, 10.4 \%$ and $12.2 \%, 14.6 \%$, respectively, and reduced total SFA by about $3.8 \%$ and $4.2 \%$, respectively. Additionally, they observed that lemongrass 
and rosemary enhanced the total CLA concentration of milk by the same amount (about 15.4\%). Hristov et al. (2013) observed no effect on milk FA profile when the diet of lactating cows was supplemented with Origanum vulgare leaves.

From the previous literature, FA of small ruminant milk was more sensitive to essential oils and phytogenic supplementation compared to the FA of cow milk, suggesting that essential oil could mitigate biohydrogenation process and potentially improve milk nutraceutical. This variation in the FA of small and large ruminants milk could be due to the rapid/faster ruminal passage rate of ingesta in the small ruminants relative to the large ruminants, which possibly restricts rumen bacteria ability or their need to complete biohydrogenation process (Nudda et al., 2014; Abd El Tawab et al., 2020).

\section{Exogenous enzymes}

Table 5 summarizes the effect of exogenous enzymes on milk FA profile. Scanty information is available on the effect and mode of action of fibrolytic enzymes supplementation on milk FA profile. However, the effect of fibrolytic enzymes on fibre digestion and ruminal acetate concentration as well as the ratio of acetate to propionate in the rumen may cause some modification of milk FA. Altering the concentrations of ruminal acetate and propionate may increase precursor availability for FA synthesis (Morsy et al., 2016). Rojo et al. (2015) fed lactating goats on diet supplemented with $2 \mathrm{~mL}$ cellulase and observed greater mono-SFA and lower total SFA. In another experiment, Kholif et al. (2018 b) observed that fibrolytic enzymes supplementation to lactating goats enhanced UFA and CLA concentrations and UFA/SFA ratio and reduced SFA contents and AI, due to the alteration of ruminal acetate and propionate concentrations, as a result of improved fibre digestibility. Recently, Azzaz et al. (2020) showed that tannase supplementation to lactating goats at 500 international unit (IU) daily increased milk contents of PUFA and total CLA. In another study, Azzaz et al. (2021) observed that tannase supplementation increased the concentration of CLA (by 13.5\%) and UFA/SFA ratio (by 9.8\%) and decreased AI (by $8.7 \%$ ). Using lactating buffaloes, Morsy et al. (2016) noted that fibrolytic enzymes mixture supplementation increased the concentrations of C16:0, cis-9, trans-11 C18:2, UFA, and total CLA, while it decreased the concentration of SFA and n-6/n-3.

\section{Effect of altering milk FA on oxidative stability and sensory characteristics}

Fatty acid profile is one of the main factors affecting oxidative stability and sensory properties of dairy and dairy products (Gebreyowhans et al., 2019; Salles et al., 2019), with fat supplementation to animals negatively effecting the oxidative stability and sensory properties. Increasing UFA concentration increases its susceptibility to oxidation, which decreases dairy and its products organoleptic properties and nutritional value (Salles et al.,
2019). Hurtaud et al. (2010) observed that supplementation of extruded linseed oil to increase the concentration of ALA from 0.23 to $0.67 \%$ of dietary FA increased rancid aroma of butter; however, Salles et al. (2019) reported that dietary incorporation of antioxidants could reduce such effect.

Jones et al. (2005) observed that fish oil supplementation did not affect flavour of cheese and butter produced from milk enriched with EPA and DHA. Others (Nelson and Martini, 2009) observed that fish oil supplementation to lactating cows did not affect oxidative stability and organoleptic properties of milk.

Supplementing diets of lactating animals with microalgae did not affect oxidative stability of milk and butter, though it improved milk and butterfat n-3 FA content (Glover et al., 2012).

\section{Conclusions}

Nutrition is the major strategy to manipulate milk and its products FA profile. Grazing pasture is the major and cheapest nutritional strategy to enhance milk FA profile. Additionally, fibre source and level are other important factors influencing milk FA, such as vaccenic acid, CLA, and PUFA. Phytogenics have marginal effect on milk FA profile, however, the effect is more pronounced in small ruminant compared to large ruminant. Dietary fats and microalgae supplementation is very effective strategies to manipulate milk FA due to their positive influence on the milk and milk products FA composition. Dietary supplementation with crude oils and oilseeds as well as microalgae are of considerable importance in terms of increasing the contents of DHA, EPA, and ALA in milk and dairy products.

\section{References}

Abd El Tawab A.M., Kholif A.E., Khattab M.S.A., Shaaban M.M., Hadhoud F.I., Mostafa M.M.M., Olafadehan O.A. (2020). Feed utilization and lactational performance of Barki sheep fed diets containing thyme or celery. Small Rumin. Res., 192: 106249.

Addis M., Cabiddu A., Pinna G., Decandia M., Piredda G., Pirisi A., Molle G. (2005). Milk and cheese fatty acid composition in sheep fed Mediterranean forages with reference to conjugated linoleic acid cis-9,trans-11. J. Dairy Sci., 88: 3443-3454.

Altomonte I., Salari F., Licitra R., Martini M. (2018). Use of microalgae in ruminant nutrition and implications on milk quality A review. Livest. Sci., 214: 25-35.

Antonacci E.L., Bussetti M., Rodriguez A.M., Cano A.V., Gagliostro G.A. (2018). Effect of diet supplementation with combinations of soybean and linseed oils on milk production and fatty acid profile in lactating dairy ewes. Agric. Sci., 09: 200-220.

Azzaz H.H., Kholif A.E., Abd El Tawab A.M., Khattab M.S.A., Murad H.A., Olafadehan O.A. (2020). A newly developed tannase enzyme from Aspergillus terreus versus commercial tannase in the diet of lactating Damascus goats fed diet containing pomegranate peel. Livest. Sci., 241: 104228.

Azzaz H.H., Kholif A.E., Murad H.A., El-Bordeny N.E., Ebeid H.M., Hassaan N.A., Anele U.Y. (2021). A new pectinase produced from Aspergillus terreus compared with a commercial pectinase enhanced feed digestion, milk production and milk fatty acid profile of Damascus goats fed pectin-rich diet. Ann. Anim. Sci., 21: 639-656. 
Bernard L., Shingfield K.J., Rouel J., Ferlay A., Chilliard Y. (2009). Effect of plant oils in the diet on performance and milk fatty acid composition in goats fed diets based on grass hay or maize silage. Br. J. Nutr., 101: 213-224.

Bernard L., Mouriot J., Rouel J., Glasser F., Capitan P., PujosGuillot E., Chardigny J.M., Chilliard Y. (2010). Effects of fish oil and starch added to a diet containing sunflower-seed oil on dairy goat performance, milk fatty acid composition and in vivo 89-desaturation of [13C]vaccenic acid. Br. J. Nutr., 104: 346-354.

Bernard L., Toral P., Rouel J., Chilliard Y. (2016). Effects of extruded linseed and level and type of starchy concentrate in a diet containing fish oil on dairy goat performance and milk fatty acid composition. Anim. Feed Sci. Technol., 222: 31-42.

Bichi E., Hervás G., Toral P.G., Loor J.J., Frutos P. (2013). Milk fat depression induced by dietary marine algae in dairy ewes: Persistency of milk fatty acid composition and animal performance responses. J. Dairy Sci., 96: 524-532.

Bodas R., Manso T., Mantecón A.R., Juárez M., De La Fuente M.Á., Gómez-Cortés P. (2010). Comparison of the fatty acid profiles in cheeses from ewes fed diets supplemented with different plant oils. J. Agric. Food Chem., 58: 10493-10502.

Bu D.P., Wang J.Q., Dhiman T.R., Liu S.J. (2007). Effectiveness of oils rich in linoleic and linolenic acids to enhance conjugated linoleic acid in milk from dairy cows. J. Dairy Sci., 90: 998-1007.

Cabiddu A., Addis M., Pinna G., Decandia M., Sitzia M., Piredda G., Pirisi A., Molle G. (2006). Effect of corn and beet pulp based concentrates on sheep milk and cheese fatty acid composition when fed Mediterranean fresh forages with particular reference to conjugated linoleic acid cis-9, trans-11. Anim. Feed Sci. Technol., 131: 292-311.

Cabiddu A., Molle G., Decandia M., Spada S., Fiori M., Piredda G., Addis M. (2009). Responses to condensed tannins of flowering sulla (Hedysarum coronarium L.) grazed by dairy sheep. Part 2 : Effects on milk fatty acid profile. Livest. Sci., 123: 230-240.

Cannas A. (2009). Feeding of lactating ewes. In: Dairy sheep nutrition. CABI, Wallingford, pp. 79-108.

Castro T., Martinez D., Isabel B., Cabezas A., Jimeno V. (2019). Vegetable oils rich in polyunsaturated fatty acids supplementation of dairy cows' diets: Effects on productive and reproductive performance. Animals, 9: 205.

Chilliard Y., Glasser F., Ferlay A., Bernard L., Rouel J., Doreau M. (2007). Diet, rumen biohydrogenation and nutritional quality of cow and goat milk fat. Eur. J. Lipid Sci. Technol., 109: $828-855$.

Chilliard Y., Martin C., Rouel J., Doreau M. (2009). Milk fatty acids in dairy cows fed whole crude linseed, extruded linseed, or linseed oil, and their relationship with methane output. J. Dairy Sci., 92: 5199-5211.

de la Torre-Santos S., Royo L.J., Martínez-Fernández A., Chocarro C., Vicente F. (2020). The mode of grass supply to dairy cows impacts on fatty acid and antioxidant profile of milk. Foods, 9: 1256.

De Renobales M., Amores G., Arranz J., Virto M., Barrón L.J.R., Bustamante M.A., Ruiz De Gordoa J.C., Nájera A.I., Valdivielso I., Abilleira E., Beltrán De Heredia I., Pérez-Elortondo F.J., Ruiz R., Albisu M., Mandaluniz N. (2012). Part-time grazing improves sheep milk production and its nutritional characteristics. Food Chem., 130: 90-96.

Dewhurst R.J., Moloney A.P. (2013). Modification of animal diets for the enrichment of dairy and meat products with omega-3 fatty acids, in: Food Enrichment with Omega-3 Fatty Acids. Elsevier, pp. 257-287.

El-Zaiat H.M., Kholif A.E., Mohamed D.A., Matloup O.H., Anele U.Y., Sallam S.M.A. (2019). Enhancing lactational performance of Holstein dairy cows under commercial production: malic acid as an option. J. Sci. Food Agric., 99: 885-892.

El-Zaiat H.M., Kholif A.E., Moharam M.S., Attia M.F., Abdalla A.L., Sallam S.M.A. (2020). The ability of tanniniferous legumes to reduce methane production and enhance feed utilization in Barki rams: in vitro and in vivo evaluation. Small Rumin. Res., 193: 106259.

Erdman J., Oria M., Pillsbury L. (2011). Eicosapentaenoic acid (EPA) and docosahexaenoic acid (DHA). In: Nutrition and traumatic brain injury: improving acute and subacute health outcomes in military personnel, J. Erdman, M. Oria, L. Pillsbury (eds). The National Academies Press, Washington, DC, pp. 188-204.

Fahim N.H., Kholif A.E., Azzaz H.H. (2022). Fennel and ginger improved nutrient digestibility and milk yield and quality in early lactating Egyptian buffaloes. Ann. Anim. Sci., 22: 255-270.

Gebreyowhans S., Lu J., Zhang S., Pang X., Lv J. (2019). Dietary enrichment of milk and dairy products with n-3 fatty acids: A review. Int. Dairy J., 97: 158-166.

Glover K.E., Budge S., Rose M., Rupasinghe H.P.V., MacLaren L., Green-Johnson J., Fredeen A.H. (2012). Effect of feeding fresh forage and marine algae on the fatty acid composition and oxidation of milk and butter. J. Dairy Sci., 95: 2797-2809.

Gomaa A.S., Kholif A.E., Kholif A.M., Salama R., El-Alamy H.A., Olafadehan O.A. (2018). Sunflower oil and Nannochloropsis oculata microalgae as sources of unsaturated fatty acids for mitigation of methane production and enhancing diets' nutritive value. J. Agric. Food Chem., 66: 1751-1759.

Gómez-Cortés P., Cívico A., De La Fuente M.A., Núñez Sánchez N., Peña Blanco F., Martinez Marin A.L. (2018). Effects of dietary concentrate composition and linseed oil supplementation on the milk fatty acid profile of goats. Animal, 12: 2310-2317.

Gutiérrez S., Svahn S.L., Johansson M.E. (2019). Effects of omega-3 fatty acids on immune cells. Int. J. Mol. Sci., 20: 5028.

Heidarian Miri V., Tyagi A.K., Ebrahimi S.H., Mohini M. (2013). Effect of cumin (Cuminum cyminum) seed extract on milk fatty acid profile and methane emission in lactating goat. Small Rumin. Res., 113: 66-72.

Hristov A.N., Lee C., Cassidy T., Heyler K., Tekippe J.A., Varga G.A., Corl B., Brandt R.C. (2013). Effect of Origanum vulgare L. leaves on rumen fermentation, production, and milk fatty acid composition in lactating dairy cows. J. Dairy Sci., 96: 1189-1202.

Hurtaud C., Faucon F., Couvreur S., Peyraud J.L. (2010). Linear relationship between increasing amounts of extruded linseed in dairy cow diet and milk fatty acid composition and butter properties. J. Dairy Sci., 93: 1429-1443.

Jones E.L., Shingfield K.J., Konen C., Jones A.K., Lupoli B., Grandison A.S., Beever D.E., Williams C.M., Calder P.C., Yaqoob P. (2005). Chemical, physical, and sensory properties of dairy products enriched with conjugated linoleic acid. J. Dairy Sci., 88: 2923-2937.

Kalač P., Samková E. (2010). The effects of feeding various forages on fatty acid composition of bovine milk fat: A review. Czech J. Anim. Sci., 55: 521-537.

Khattab M.S.A., El-Zaiat H.M., El Tawab A.M.A., Matloup O.H., Morsy A.S., Abdou M.M., Ebeid H.M., Attia M.F.A., Sallam S.M.A. (2017). Impact of lemongrass and galangal as feed additives on performance of lactating Barki goats. Int. J. Dairy Sci., 12: $184-189$.

Kholif A.E., Gouda G.A., Morsy T.A., Salem A.Z.M., Lopez S., Kholif A.M. (2015). Moringa oleifera leaf meal as a protein source in lactating goat's diets: Feed intake, digestibility, ruminal fermentation, milk yield and composition, and its fatty acids profile. Small Rumin. Res., 129: 129-137.

Kholif A.E., Morsy T.A., Abd El Tawab A.M., Anele U.Y., Galyean M.L. (2016 a). Effect of supplementing diets of Anglo-Nubian goats with soybean and flaxseed oils on lactational performance. J. Agric. Food Chem., 64: 6163-6170.

Kholif A.E., Morsy T.A., Gouda G.A., Anele U.Y., Galyean M.L. (2016 b). Effect of feeding diets with processed Moringa oleifera meal as protein source in lactating Anglo-Nubian goats. Anim. Feed Sci. Technol., 217: 45-55.

Kholif A.E., Matloup O.H., Morsy T.A., Abdo M.M., Abu Elella A.A., Anele U.Y., Swanson K.C. (2017 a). Rosemary and lemongrass herbs as phytogenic feed additives to improve efficient feed utilization, manipulate rumen fermentation and elevate milk production of Damascus goats. Livest. Sci., 204: 39-46.

Kholif A.E., Morsy T.A., Matloup O.H., Anele U.Y., Mohamed A.G., El-Sayed A.B. (2017 b). Dietary Chlorella vulgaris microalgae improves feed utilization, milk production and concentrations of conjugated linoleic acids in the milk of Damascus goats. J. Agric. Sci., 155: 508-518. 
Kholif A.E., Gouda G.A., Olafadehan O.A., Abdo M.M. (2018 a). Effects of replacement of Moringa oleifera for berseem clover in the diets of Nubian goats on feed utilisation, and milk yield, composition and fatty acid profile. Animal, 12: 964-972.

Kholif A.E., Kassab A.Y., Azzaz H.H., Matloup O.H., Hamdon H.A., Olafadehan O.A., Morsy T.A. (2018 b). Essential oils blend with a newly developed enzyme cocktail works synergistically to enhance feed utilization and milk production of Farafra ewes in the subtropics. Small Rumin. Res., 161: 43-50.

Kholif A.E., Morsy T.A., Abdo M.M. (2018 c). Crushed flaxseed versus flaxseed oil in the diets of Nubian goats: Effect on feed intake, digestion, ruminal fermentation, blood chemistry, milk production, milk composition and milk fatty acid profile. Anim. Feed Sci. Technol., 244: 66-75.

Kholif A.E., Gouda G.A., Galyean M.L., Anele U.Y., Morsy T.A. (2019). Extract of Moringa oleifera leaves increases milk production and enhances milk fatty acid profile of Nubian goats. Agrofor. Syst., 93: 1877-1886.

Kholif A.E., Gouda G.A., Hamdon H.A. (2020 a). Performance and milk composition of Nubian goats as affected by increasing level of Nannochloropsis oculata microalgae. Animals, 10: 1-14.

Kholif A.E., Hamdon H.A., Kassab A.Y., Farahat E.S.A., Azzaz H.H., Matloup O.H., Mohamed A.G., Anele U.Y. (2020 b). Chlorella vulgaris microalgae and/or copper supplementation enhanced feed intake, nutrient digestibility, ruminal fermentation, blood metabolites and lactational performance of Boer goat. J. Anim. Physiol. Anim. Nutr. (Berl.), 104: 1595-1605.

Kholif A.E., Olafadehan O.A. (2021). Essential oils and phytogenic feed additives in ruminant diet: chemistry, ruminal microbiota and fermentation, feed utilization and productive performance. Phytochem. Rev., 20: 1087-1108.

Kholif A.E., Hassan A.A., El Ashry G.M., Bakr M.H., El-Zaiat H.M., Olafadehan O.A., Matloup O.H., Sallam S.M.A. (2021 a). Phytogenic feed additives mixture enhances the lactational performance, feed utilization and ruminal fermentation of Friesian cows. Anim. Biotechnol., 32: 708-718.

Kholif A.E., Hassan A.A., Matloup O.H., El Ashry G.M. (2021 b) Top-dressing of chelated phytogenic feed additives in the diet of lactating Friesian cows to enhance feed utilization and lactational performance. Ann. Anim. Sci., 21: 657-667.

Kholif A.E., Kassab A.Y., Hamdon H.A. (2021 c). Chlorella vulgaris microalgae and copper mixture supplementation enhanced the nutrient digestibility and milk attributes in lactating boer goats. Ann. Anim. Sci., 21: 939-957.

Kholif A.E., Matloup O.H., Hadhoud F.I., Kassab A.Y., Adegbeye M.J., Hamdon H.A. (2021 d). Lemongrass supplementation to Farafra ewes improved feed utilization, lactational performance and milk nutritive value in the subtropics. Anim. Biotechnol., https://doi.org/10.1080/10495398.2020.1870485

Kliem K.E., Morgan R., Humphries D.J., Shingfield K.J., Givens D.I. (2008). Effect of replacing grass silage with maize silage in the diet on bovine milk fatty acid composition. Animal, 2: $850-1858$.

Kliem K.E., Humphries D.J., Kirton P., Givens D.I., Reynolds C.K. (2019). Differential effects of oilseed supplements on methane production and milk fatty acid concentrations in dairy cows. Animal, 13: 309-317.

Kupczyński R., Szołtysik M., Janeczek W., Chrzanowska J., Kinal S., Króliczewska B. (2011). Effect of dietary fish oil on milk yield, fatty acids content and serum metabolic profile in dairy cows. J. Anim. Physiol. Anim. Nutr. (Berl.), 95: 512-522.

Lum K.K., Kim J., Lei X.G. (2013). Dual potential of microalgae as a sustainable biofuel feedstock and animal feed. J. Anim. Sci. Biotechnol., 4: 1-7.

Martínez Marín A.L., Gómez-Cortés P., Gómez Castro A.G., Juárez M., Pérez Alba L.M., Pérez Hernández M., de la Fuente M.A. (2011). Animal performance and milk fatty acid profile of dairy goats fed diets with different unsaturated plant oils. J. Dairy Sci., 94: 5359-5368.

Moate P.J., Williams S.R.O., Hannah M.C., Eckard R.J., Auldist M.J., Ribaux B.E., Jacobs J.L., Wales W.J. (2013). Effects of feeding algal meal high in docosahexaenoic acid on feed intake, milk pro- duction, and methane emissions in dairy cows. J. Dairy Sci., 96: $3177-3188$

Mohammed R., Stanton C.S., Kennelly J.J., Kramer J.K.G., Mee J.F., Glimm D.R., O'Donovan M., Murphy J.J. (2009). Grazing cows are more efficient than zero-grazed and grass silage-fed cows in milk rumenic acid production. J. Dairy Sci., 92: 3874-3893.

Moran C.A., Morlacchini M., Keegan J.D., Fusconi G. (2018). The effect of dietary supplementation with Aurantiochytrium limacinum on lactating dairy cows in terms of animal health, productivity and milk composition. J. Anim. Physiol. Anim. Nutr. (Berl.), 102: $576-590$.

Morsy T.A., Kholif S.M., Kholif A.E., Matloup O.H., Salem A.Z.M., Elella A.A. (2015). Influence of sunflower whole seeds or oil on ruminal fermentation, milk production, composition, and fatty acid profile in lactating goats. Asian-Australasian J. Anim. Sci., 28: $1116-1122$

Morsy T.A., Kholif A.E., Kholif S.M., Kholif A.M., Sun X., Salem A.Z.M. (2016). Effects of two enzyme feed additives on digestion and milk production in lactating Egyptian buffaloes. Ann. Anim. Sci., 16: 209-222.

Morsy T.A., Kholif A.E., Matloup O.H., Elella A.A., Anele U.Y., Caton J.S. (2018). Mustard and cumin seeds improve feed utilisation, milk production and milk fatty acids of Damascus goats. J. Dairy Res., 85: 142-151.

Mozzon M., Frega N.G., Fronte B., Tocchini M. (2002). Effect of dietary fish oil supplements on levels of n-3 polyunsaturated fatty acids, trans acids and conjugated linoleic acid in ewe milk. Food Technol. Biotechnol., 40: 213-219.

Nelson K.A.S., Martini S. (2009). Increasing omega fatty acid content in cow's milk through diet manipulation: Effect on milk flavor. J. Dairy Sci., 92: 1378-1386.

Novotná K., Fantová M., Nohejlová L., Borková M., Stádník L., Ducháček J. (2017). Effect of Chlorella vulgaris and Japonochytrium sp. microalgae supplementation on composition and fatty acid profile of goat milk. Acta Univ. Agric. Silvic. Mendelianae Brun., 65: 1585-1593.

Nudda A., Battacone G., Neto O.B., Cannas A., Francesconi A.H.D., Atzori A.S., Pulina G. (2014). Feeding strategies to design the fatty acid profile of sheep milk and cheese. Rev. Bras. Zootec., 43: 445-456.

Pajor F., Egerszegi I., Steiber O., Bodnár Á., Póti P. (2019). Effect of marine algae supplementation on the fatty acid profile of milk of dairy goats kept indoor and on pasture. J. Anim. Feed Sci., 28: 169-176.

Pajor F., Egerszegi I., Szűcs Á., Póti P., Bodnár Á. (2021). Effect of marine algae supplementation on somatic cell count, prevalence of udder pathogens, and fatty acid profile of dairy goats' milk. Animals, 11: 1097.

Pi Y., Gao S.T., Ma L., Zhu Y.X., Wang J.Q., Zhang J.M., Xu J.C., Bu D.P. (2016). Effectiveness of rubber seed oil and flaxseed oil to enhance the $\alpha$-linolenic acid content in milk from dairy cows. J. Dairy Sci., 99: 5719-5730.

Pintus S., Murru E., Carta G., Cordeddu L., Batetta B., Accossu S., Pistis D., Uda S., Ghiani M.E., Mele M., Secchiari P., Almerighi G., Pintus P., Banni S. (2013). Sheep cheese naturally enriched in $\alpha$-linolenic, conjugated linoleic and vaccenic acids improves the lipid profile and reduces anandamide in the plasma of hypercholesterolaemic subjects. Brit. J. Nutr., 109: 1453-1462.

Pulina G., Nudda A., Battacone G., Cannas A. (2006). Effects of nutrition on the contents of fat, protein, somatic cells, aromatic compounds, and undesirable substances in sheep milk. Anim. Feed Sci. Technol., 131: 255-291.

Rego O.A., Cabrita A.R.J., Rosa H.J.D., Alves S.P., Duarte V., Fonseca A.J.M., Vouzela C.F.M., Pires F.R., Bessa R.J.B. (2016). Changes in milk production and milk fatty acid composition of cows switched from pasture to a total mixed ration diet and back to pasture. Ital. J. Anim. Sci., 15: 76-86.

Rojo R., Kholif A.E., Salem A.Z.M., Elghangour M.M.Y., Odongo N.E., Montes de Oca R., Rivero N., Alonso M.U. (2015). Influence of cellulase addition to dairy goat diets on digestion and fermentation, milk production and fatty acid content. J. Agric. Sci., 153: 1514-1523. 
Sallam S.M.A., Attia M.F.A., Nour El-Din A.N.M., El-Zarkouny S.Z., Saber A.M., El-Zaiat H.M., Zeitoun M.M. (2019). Involvement of Quebracho tannins in diet alters productive and reproductive efficiency of postpartum buffalo cows. Anim. Nutr., 5: 80-86.

Sallam S.M.A., Kholif A.E., Kadoom M.H.A., Nour El-Din A.N.M., Attia M.F.A., Matloup O.H., Olafadehan O.A. (2021). Effect of different levels of protected palmitic acid-enriched fat supplement on lactational performance of Holstein cows and feed utilization of Barki sheep. Agric. Conspec. Sci., 86: 153-163.

Salles M.S.V., D’abreu L.F., Júnior L.C.R., César M.C., Guimarães J.G.L., Segura J.G., Rodrigues C., Zanetti M.A., Pfrimer K., Netto A.S. (2019). Inclusion of sunflower oil in the bovine diet improves milk nutritional profile. Nutrients, 11: 481.

Shaaban M.M., Kholif A.E., Abd El Tawab A.M., Radwan M.A., Hadhoud F.I., Khattab M.S.A., Saleh H.M., Anele U.Y. (2021). Thyme and celery as potential alternatives to ionophores use in livestock production: their effects on feed utilization, growth performance and meat quality of Barki lambs. Small Rumin. Res., 200: 106400

Sofi F., Buccioni A., Cesari F., Gori A.M., Minieri S., Mannini L., Casini A., Gensini G.F., Abbate R., Antongiovanni M. (2010). Effects of a dairy product (pecorino cheese) naturally rich in cis9, trans-11 conjugated linoleic acid on lipid, inflammatory and haemorheological variables: A dietary intervention study. Nutr. Metab. Cardiovasc. Dis., 20: 117-124.

Stamey J.A., Shepherd D.M., de Veth M.J., Corl B.A. (2012). Use of algae or algal oil rich in n-3 fatty acids as a feed supplement for dairy cattle. J. Dairy Sci., 95: 5269-5275.

Suksombat W., Thanh L.P., Meeprom C., Mirattanaphrai R. (2016). Effect of linseed oil supplementation on performance and milk fatty acid composition in dairy cows. Anim. Sci. J., 87: 1545-1553.

Thanh L.P., Suksombat W. (2015). Milk yield, composition, and fatty acid profile in dairy cows fed a high-concentrate diet blended with oil mixtures rich in polyunsaturated fatty acids. Asian-Australas. J. Anim. Sci., 28: 796-806.

Till B.E., Huntington J.A., Kliem K.E., Taylor-Pickard J., Sinclair L.A. (2020). Long term dietary supplementation with microalgae increases plasma docosahexaenoic acid in milk and plasma but does not affect plasma 13,14-dihydro-15-keto PGF2 $\alpha$ concentration in dairy cows. J. Dairy Res., 87: 14-22.

Toral P.G., Hervás G., Gómez-Cortés P., Frutos P., Juárez M., de la Fuente M.A. (2010). Milk fatty acid profile and dairy sheep performance in response to diet supplementation with sunflower oil plus incremental levels of marine algae. J. Dairy Sci., 93: 16551667.

Toral P.G., Hervás G., Belenguer A., Bichi E., Frutos P. (2013). Effect of the inclusion of quebracho tannins in a diet rich in linoleic acid on milk fatty acid composition in dairy ewes. J. Dairy Sci., 96: 431-439.

Toral P.G., Rouel J., Bernard L., Chilliard Y. (2014). Interaction between fish oil and plant oils or starchy concentrates in the diet: Effects on dairy performance and milk fatty acid composition in goats. Anim. Feed Sci. Technol., 198: 67-82.

Tripathi M.K. (2015). Effect of nutrition on production, composition, fatty acids and nutraceutical properties of milk. Adv. Dairy Res., 2: $1-11$.

Vafa T.S., Naserian A.A., Moussavi A.R.H., Valizadeh R., Mesgaran M.D. (2012). Effect of supplementation of fish and canola oil in the diet on milk fatty acid composition in early lactating Holstein cows. Asian-Australas. J. Anim. Sci., 25: 311-319.

Vargas-Bello-Pérez E., Cancino-Padilla N., Geldsetzer-Mendoza C., Vyhmeister S., Morales M.S., Leskinen H., Romero J., Garnsworthy P.C., Ibáñez R.A. (2019). Effect of feeding cows with unsaturated fatty acid sources on milk production, milk composition, milk fatty acid profile, and physicochemical and sensory characteristics of ice cream. Animals, 9: 568.

Vlaeminck B., Fievez V., Cabrita A.R.J., Fonseca A.J.M., Dewhurst R.J. (2006). Factors affecting odd- and branched-chain fatty acids in milk: A review. Anim. Feed Sci. Technol., 131: 389-417.

Received: 20 III 2021

Accepted: 15 VII 2021 